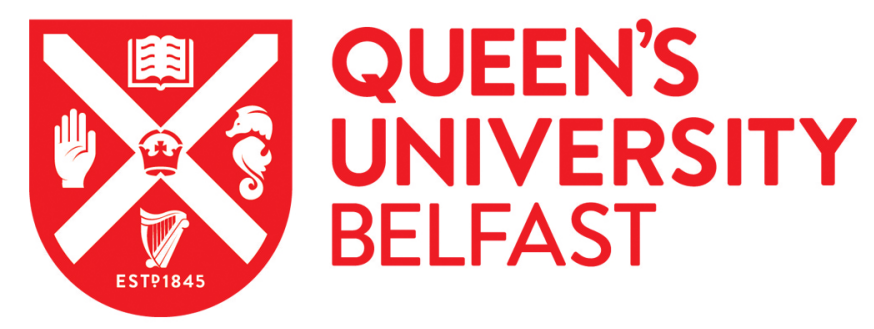

\title{
The continued salience of religious voting in the United States, Germany, and Great Britain
}

Raymond, C. (2011). The continued salience of religious voting in the United States, Germany, and Great Britain. Electoral Studies, 30(1), 125-135. https://doi.org/10.1016/j.electstud.2010.10.001

\author{
Published in: \\ Electoral Studies
}

Document Version:

Peer reviewed version

Queen's University Belfast - Research Portal:

Link to publication record in Queen's University Belfast Research Portal

Publisher rights

(c) 2010 Elsevier Ltd. This manuscript version is made available under the CC-BY-NC-ND 4.0 license http://creativecommons.org/licenses/bync-nd/4.0/), which permits distribution and reproduction for non-commercial purposes, provided the author and source are cited.

\section{General rights}

Copyright for the publications made accessible via the Queen's University Belfast Research Portal is retained by the author(s) and / or other copyright owners and it is a condition of accessing these publications that users recognise and abide by the legal requirements associated with these rights.

Take down policy

The Research Portal is Queen's institutional repository that provides access to Queen's research output. Every effort has been made to ensure that content in the Research Portal does not infringe any person's rights, or applicable UK laws. If you discover content in the Research Portal that you believe breaches copyright or violates any law, please contact openaccess@qub.ac.uk. 


\title{
The Continued Salience of Religious Voting in the United States, Germany, and Great Britain*
}

\author{
Christopher Raymond $^{\text {a }}$
}

\begin{abstract}
Conventional wisdom on party systems in advanced industrial democracies holds that modern electorates are dealigned and that social cleavages no longer structure party politics. Recent work on class cleavages has challenged this stylized fact. The analysis performed here extends this criticism to the religious-secular cleavage. Using path analysis and comparing the current electorates of the United States, Germany, and Great Britain with the early 1960s, this paper demonstrates that the religious-secular cleavage remains or has become a significant predictor of conservative vote choice. While the effects of the religious-secular cleavage on vote choice have become largely indirect, the total of the direct and indirect effects are substantial and equivalent to the effects of class and status.
\end{abstract}

Keywords: Religious voting; Social cleavages; Party systems; Religiosity

\section{Acknowledgements}

I would like to thank John Petrocik and Leslie Schwindt-Bayer for commenting on previous drafts of this paper, and Ted Jelen, who provided useful suggestions - which were integrated into this paper - at the 2009 Annual Meeting of the Midwest Political Science Association. While I appreciate their many helpful suggestions, the responsibility for the contents of this paper (both positive and negative) is solely mine.

*Appeared in Electoral Studies (2011), volume 30, issue 1, pp. 125-135.

${ }^{a}$ PhD Candidate, Department of Political Science, University of Missouri, Columbia, MO (cdrxdd@mail.missouri.edu) 


\section{Introduction}

The current state of the literature on party systems maintains that electorates are dealigned from their political parties (Dalton, 2006; Franklin, Mackie, and Valen, 1992; Knutsen, 2006; Daalder and Mair, 1983; Dalton, Flanagan, and Beck, 1984). Where close ties between the principal social divisions of society and the political parties once existed, electorates now are considered "floating” without party loyalties (Dalton and Wattenberg, 2000). These studies have focused on how the effects of social characteristics become insignificant when in the presence of the more proximate determinants of the vote, such as ideology, issues, candidate evaluations, and retrospective voting (Lewis-Beck, 1988; Franklin, 1985; Inglehart and Klingemann, 1976; Inglehart, 1984; Knutsen, 1988). However, examining the effect of the social cleavages in this way potentially masks their continued importance for structuring the party system, because social cleavages may determine those more proximate predictors of vote choice. This oversight has led to potentially erroneous conclusions that the sociopolitical cleavages in contemporary voting behavior no longer have important effects.

A burgeoning literature argues that such statements as the "death of class" and other social cleavages are premature or even unfounded. ${ }^{1}$ This is particularly so with regard to the religious-secular divide (Layman, 2001; Norris and Inglehart, 2004; Mulligan, 2008; Layman and Carmines, 1997; Elff, 2007, 2009; Ang and Petrocik, n.d.). As the social cleavage dividing the religious from the secular has intensified over time despite secularization, so has the political cleavage: religious voters have become an increasingly tempting base of support for conservative parties to target, given religious voters' inclinations toward conservative moral traditionalism and seculars' general affinity for moral progressivism (Layman and Carmines, 1997).

\footnotetext{
${ }^{1}$ This literature is too long to cite adequately here, but important recent works include, Bartolini and Mair, (1990); Elff (2007, 2009); Weakliem (1995); Manza Hout, and Brooks (1995); Brooks and Manza (1997); Chan and Goldthorpe (2007); van der Waal, Achterberg, and Houtman (2007).
} 
This paper examines the effect of the religious-secular cleavage in relation to the other traditional social cleavages within the contexts of the United States, Germany, and Great Britain in order to determine if the religious-secular divide remains a meaningful source of political conflict. These three cases present an interesting test of the salience of the religious-secular cleavage because they represent three different trends in the strength of the religious cleavage within the literature: a declining trend in religious voting in Germany, an upward trend in the United States, and no trend, remaining low in Britain. By examining the effects of the social cleavages on partisanship and vote choice over time, this paper tests whether the religioussecular divide still affects vote choices in these three electorates.

Additionally, this paper examines the effects of the religious cleavage on three short-term forces (left-right self-placement, party leader preference, and economic evaluations) argued to have displaced social cleavage effects. Following the logic of the Michigan model's funnel of causality (see Dalton, 2006: 178; Lewis-Beck et al., 2008: 23), incorporating social cleavage variables and short-term forces into the same model, without first dealing with problems of endogeneity, masks the persistence of the religious-secular cleavage. The analyses show that social cleavages structure the more proximate determinants of vote choice. After dealing with these problems of endogeneity, the effects of religious voting remain sizable, especially when compared with class and status effects as well as with the short-term forces. These findings support the argument that the religious-secular cleavage remains an important determinant of vote choices in these three countries, and perhaps cross-nationally as well.

\section{Weakening Social Cleavages}

The social cleavage approach to the study of party systems, as articulated by Lipset and Rokkan (1967), argues that party systems "freeze" around the principal social divisions at the 
outset of democratization, which in turn structure the economic and social conflicts that come to form the bases of party systems. While Lipset and Rokkan emphasized the impact of class, religion was also noted as a significant source of electoral support. Rose and Urwin (1969) differed from Lipset and Rokkan slightly by documenting that while class was indeed one of the most important bases of party systems cross-nationally, religious divisions surpassed class as the principal basis. The general findings of these seminal studies of the formation and freezing of party systems appeared confirmed by other research conducted around the same time (see Rose, 1974).

However, other researchers took notice of the increasing electoral volatility in late 1960s and 1970s and began to question whether electorates really were "frozen" around the principal social cleavages (Pederson, 1983; Dalton 1996; 2006). As a result of changing social conditions - including the post-War economic boom, higher levels of education, and the secularization of society - many scholars began to contend that a dealigning process was taking place in which the ties between social groups and parties had broken (Daalder and Mair, 1983; Dalton, Flanagan, and Beck, 1984; Dalton, 2000; Dalton, McAllister, and Wattenberg, 2000; Franklin, Mackie, and Valen, 1992). Cross-nationally, the major parties have experienced significant declines in membership and partisanship; even those who identify with a political party do so with less vigor than before (Dalton, 2000, 2006; Arzheimer, 2006; Zelle, 1998). While most scholarship on the subject has focused on the class dealignment ${ }^{2}$ (Franklin, 1985; Robertson, 1984; Heath et al., 1991; Knutsen, 2006; Lane and Ersson 1999; Manza, Hout, and Brooks, 1995; Brooks and Manza, 1997; Rose and McAllister, 1990; van der Waal, Achterberg, and Houtman, 2007; Weakliem, 1995; Dalton, 1996; van der Waal et al., 2007), other works have made the same case with regard to the religious-secular cleavage (Dalton, 1996, 2006;

\footnotetext{
${ }^{2}$ For a dissenting voice on topic of class dealignment using ecological data, see Bartolini and Mair (1990).
} 
Franklin, Mackie, and Valen, 1992; Knutsen, 2004). As a result of declining rates of religious observance and the overall secularization of society, these authors contend that religious beliefs these days have less direct influence on individuals' voting calculi than forty years ago (Franklin, Mackie, and Valen, 1992; Knutsen, 2004).

Some have viewed this dealignment as a precursor to an eventual realignment of party loyalties among social groups (Petrocik, 1987). Yet others have argued that electoral volatility and party dealignment have become permanent features of modern electorates. These scholars have shown that while voters have become less partisan, they have instead become more ideological (Inglehart and Klingemann, 1976; Inglehart, 1984; Knutsen, 1988) and have experienced a transformation of values from material to postmaterial concerns and 'new politics' issues (Inglehart, 1977, 1997). Issues, candidate and economic evaluations also have become more proximate to individuals' vote choices than traditional social divisions (Franklin, 1985; Lewis-Beck, 1988; Schoen, 2007; Vetter and Gabriel, 1998; Dalton, 1996, 2006).

As a result of these changes in the electorates, political parties have come to reflect the changing nature of the times. This can be seen, for instance, in the 'new politics' stances of "New Labour" which dropped clause four (calling for the complete nationalization of industry) in the early nineties and reflected a shift in their electoral strategy of targeting voters at the political center - in this case, middle class employees who hold leftist-libertarian values. This follows a broader pattern of similar realignments and repositioning by parties of the left elsewhere (Lipset, 2001). This shifting of electoral strategies represents larger changes which have occurred in party systems cross-nationally. Further evidence of party system change can be seen with the return of the Liberals (now Liberal Democrats) as a viable political party in Great Britain, with the rise of the Greens in Germany, and with the realignment associated with the 
breakup of the New Deal coalition in the United States (Petrocik, 1987). In each case, the parties have responded to the changes induced by the emergence of the 'new values' cleavage(s) and significant shifts in the party system have occurred at the individual level as a result.

\section{The Continued Salience of the Religious Cleavage}

Most of the studies on realignment and coalition shifts have focused on the social democratic parties of the political left or the extremist parties of the right with particular interest in class alignments (see Veugelers, 2001; Oesch, 2008). However, emerging research suggests that religious values also continue to form an important base of electoral support for parties of the right. Although religious observance has declined significantly in recent years, emerging evidence suggests that those who remain faithful continue to comprise a highly salient political cleavage cross-nationally (Elff, 2007, 2009; Layman, 2001; Schmitt, 1998; Norris and Inglehart, 2004; Norris, 1997; Ang and Petrocik, n.d.). In fact, religious-secular differences remain the best predictor of vote choice among the traditional social cleavages (Dalton, 1996). If anything, recent theoretical developments suggest that instead of diminishing, the political salience of religious-secular differences actually increases with societal development and secularization as the demand for religious services increases among those who remain religiously faithful (Gaskins, Golder, and Siegel, n.d.).

One can see why the religious-secular divide remains one of the most significant predictors of political behavior among the social cleavages if one considers some of the characteristics religious voters share. For one, the average religious voter self-locates on the more traditional end of the political values spectrum (Layman and Carmines, 1997; de Koster and van der Waal, 2007; De Witte and Billiet, 1999), supporting traditional values and issues of morality, positions which lend themselves to support for more conservative parties of the right 
(Hammond, Shibley, and Solow, 1994; Layman, 2001; Mulligan, 2008; Hout and Fisher, 2002;

Djupe, 2000; Green and Guth, 1993). Because churches and the sub-communities that churches create foster intense political socialization (Wald, Hill, and Owen, 1988) and facilitate mobilization for campaigns and voting (Verba, Schlozman, and Brady, 1995; Campbell, 2004), the moral traditionalism and general conservatism of many religious voters makes them tempting targets for conservative parties seeking to realign their bases with ardent, faithful supporters.

While religious and other specific cleavage-based voting is often associated with multiparty systems where parties have strong social group ties (Powell, 1986), religious voters need not have a political party that targets their votes and explicitly pursues religious issues in parliamentary settings (as with the CDU in Germany) in order to constitute a meaningful social base of support. So long as a political party is identified by the electorate with certain issues of political salience — e.g. abortion, moral traditionalism, etc.—-to religious voters (Petrocik, 1996), their interests can be articulated and votes targeted by conservative parties. Even in two-party settings, parties of the right can effectively court the support of religious voters without turning off other voters. Petrocik (n.d.) has shown that in the case of the United States, the Republicans have increasingly catered to- and received the support of religious voters. Kotler-Berkowitz (2001) has similarly demonstrated that the Conservatives in Britain are the main beneficiaries of religious voters.

A large part of what makes religious voters so tempting as a base of conservative political support is that their social values tend to correspond with conservative political values, which in turn facilitates conservative party identification and voting. Put another way, religiosity remains a powerful predictor because it has substantial indirect effects on conservative vote choice through its effects on political values and party identification. Following the funnel of causality 
in the Michigan model of voting behavior (see Dalton 2006: 178), social cleavages (in this case, the religious-secular cleavage) are hypothesized to have indirect effects on the vote through their impact on value orientations (e.g. left-right ideology, postmaterialism, etc.) and party identification. Thus, if the Michigan model is to be believed, religiosity should affect the more proximate predictors of vote choice.

The evidence suggests that social cleavages do affect these more proximate predictors of vote choice, and thus may in fact have indirect effects on vote choice as the Michigan model supposes. In Britain, Prandy (2000) shows that social class still matters as a predictor of party identification. The same effect on party identification has been observed with regard to religion (Layman, 2001; Djupe, 2000; Johnson, 1994; Kotler-Berkowitz, 2001). Religiosity also appears to affect left-right and other political value orientations (Inglehart and Klingemann, 1976; Inglehart, 1984; Hammond, Shibley, and Solow, 1994; Jagodzinski and Kühnel, 1998; Johnson, 1994) much as class has been shown to affect the left-right scale (Chan and Goldthorpe, 2007; Bartle, 1998). Additionally, religion has been shown to have an effect on other social value orientations associated with vote choice as well (Layman and Carmines, 1997; de Koster and van der Waal, 2007; De Witte and Billiet, 1999).

What these studies all suggest is that while social cleavages (in this case, the religioussecular divide) may not directly affect vote choice, they do structure party identification, value orientations, and other short-term factors that are considered to be the more proximate predictors of vote choice. Accounting for not only the direct but also the indirect effects of religiosity may demonstrate that the religious-secular divide continues to structure voting behavior in advanced industrial democracies. However, such an argument has not been tested empirically. Considering the lack of scholarly focus on both the direct and indirect effects of religiosity on 
voting behavior, those arguments purporting a decrease in the importance of religiosity and other social cleavages for predicting voting behavior may be inaccurate. This analysis corrects this deficiency by accounting for these endogeneity problems in order to present an accurate assessment of the effects of the social cleavages on vote choice.

\section{Data and Methods}

The analysis proceeds in two stages. First, the more volatile electorates of today are compared and contrasted with the electorates of the 1960s, prior to the period of dealignment. This is done in order to determine whether the effects of the religious cleavage have decreased from the 1960s to the present day as the literature suggests. Second, the relationships between social cleavages and the variables previous literature argues to be most proximate to vote choice are examined. This second stage deals with the endogeneity problems in the arguments holding that the social cleavages no longer matter to explaining vote choices. Three countries are selected because they represent three different patterns of associations between social cleavages and vote choice: a downward trend in Germany, an upward trend in the United States, and no clear trend in Great Britain (Knutsen, 2004, 2006). This provides appropriate variation and generalizability in order to test whether the effect of religiosity has declined in salience to vote choice.

The data for the 1960s are taken from the Butler and Stokes Political Change in Britain surveys and the American and German National Elections Studies (ANES and GES, respectively). The corresponding years for the three election surveys are $1964,1960,{ }^{3}$ and 1965 (October), respectively. Recent election data come from the first wave of the Comparative Study of Electoral Systems (CSES), corresponding with the 1996 US presidential election, the 1997

\footnotetext{
${ }^{3}$ Because of the salience of Kennedy's religious practice, the 1960 ANES may be an outlier in terms of the high level of polarization between Catholics and Protestants, which may underestimate the effect of religious-secular differences. To ensure against this, I compared the results from the 1960 ANES with the 1956 ANES and found that the rate of religious-secular polarization to be higher in 1960 than 1956. Thus, the choice of 1960 appears to appropriately test the arguments proposed here.
} 
British general election, and the party list ballot (Zweitstimme) for the 1998 German Bundestag elections. ${ }^{4}$ For the sake of comparability across time, only data from West Germany are used from the 1998 German election. All data were accessed online through the Inter-University Consortium for Political and Social Research at the University of Michigan.

The two dependent variables used in the first stage of the analysis are (1) respondent vote choice and (2) party identification. Using party identification in addition to vote choice provides a robustness check because the social dealignment literature discussed above suggests that the links between social cleavages and party identification have been severed much like the links between social cleavages and vote choices. Because religious voting is a generally conservative phenomenon in advanced democracies, a binary distinction is made between conservative and all other parties. Conservative parties in these three cases include the Christian Democratic Union and Christian Social Union in Germany, the Conservative Party in Great Britain, and the Republican Party in the United States. Probit regression is used for these analyses.

The main independent variable, the religious-secular cleavage, is measured as frequency of attendance of religious services. To deal with potential spuriousness, the effects of the religious-secular divide are examined in relation to other social cleavages. The other variables include three measures of status and class ${ }^{5}$ - income, union membership, and attainment of a

\footnotetext{
${ }^{4}$ To ensure that the analyses and results reported here were not specific to the elections examined here, the results derived from the first wave of the CSES were compared to the second wave of the CSES as a robustness check. Using the second wave of the CSES did not alter the results and conclusions presented here in a substantial way. These results are presented in the Supplementary Material section.

${ }^{5}$ While it would have been desirable to include additional, direct measures of class (i.e. variables that specifically measure occupational differences between middle and working class positions), comparable data for objective and subjective class variables were not available in all the election surveys. However, the variables employed here adequately tap the differences between the haves and have-nots: income differentials measures the differences in material benefits derived from employment, union membership controls for class consciousness, and including a binary variable for university graduates addresses the effects of higher education on status attainment.
} 
university degree — voting disparities among religious denominations, ${ }^{6}$ gender, a variable controlling for urban residence, long-term regional voting disparities - southern states in the US (Black and Black, 1987) and Scotland in the UK (Bennie, Brand, and Mitchell, 1997)—and a variable controlling for African Americans in the United States. All missing responses are listwise deleted. Because my focus is restricted primarily to the religious-secular cleavage—and the class/status cleavage for the sake of comparison-I do not present parameter estimates for all of the variables (though these can be obtained from the author upon request). See the Appendix below for detailed explanations of variable measurements.

Because the Michigan model suggests that social cleavages ultimately have indirect effects on vote choice, the effects of the social cleavages on the more proximate determinants of vote choice are also examined. Relying solely on the first wave of the CSES because of data availability for the short-term forces, three such measures are chosen. These include left-right ideological self-placement, a measure of party leader preference for the leader of the party of the right used in the dependent variable, and evaluations of recent economic performance. Left-right self-placement and party leader preference are both measured ranging from zero to ten. Low values on the left-right scale correspond with the political left and higher values with the political right. Low values of candidate/party leader preference represent animosity towards the party leader while higher values correspond with favorability. Economic performance ranges from one to five, where one represents very good economic performance and five represents very bad economic performance evaluations. While these three variables tested here are only an approximation of the larger Michigan model's funnel of causality (see Lewis-Beck et al., 2008: 23; Dalton, 2006: 178), the three variables represent some of the more important determinants of

\footnotetext{
${ }^{6}$ This variable is intended to control for the denominations most likely to vote for the conservative parties in order to demonstrate that the religious-secular divide is occurring across denominations. The denominations included under this heading include Catholics in Germany, Anglicans in Britain, and Protestants in the United States.
} 
vote choice noted by the literature. In the second stage of the analysis, these variables are analyzed with linear regression estimated by ordinary least squares with robust standard errors. ${ }^{7}$ The hypothesized model is presented in Figure $1 .{ }^{8}$

\section{Figure 1 about here}

The model in Figure 1 suggests that while social cleavages have some direct effects on vote choice, their primary impact is through other variables that are more proximate to vote choice. If these more proximate determinants of vote choice are themselves determined by social cleavages, this would call into question arguments purporting that social divisions matter less to modern party systems today than in years past. For instance, the explanatory power of economic evaluations to predict vote choice that is attributable to the relevant social cleavages would be indicative of an indirect social cleavage effect on vote choice. Because few would argue that economic evaluations are causally prior to social demographics, any variance shared between economic evaluations and religiosity that predicts vote choice is causally attributable to the religiosity. Thus, it makes little sense to include both variables in the same model without dealing with this endogeneity problem; failure to do so results in problematic interpretations of the actual effect of social cleavages on vote choice because any shared variance between social cleavages and the more proximate determinants of vote choice results in statistical insignificance for the social cleavage variables, when in fact such variables have both direct and indirect effects (through the endogenous variable) on vote choice. Previous studies often, however, include all variables relevant to vote choice without dealing with endogeneity problems.

\footnotetext{
${ }^{7}$ See footnote 11 below with regard to the treatment of economic evaluations with different estimators.

${ }^{8}$ An alternative model that more closely approximates the larger Michigan model includes party identification as a mediating variable between social cleavages and the more proximate, short-term forces. Because of the longstanding critiques of the Michigan model concept of party identification - regarding the responsiveness of party identification to short-term forces like retrospective evaluations (Fiorina, 1981) — and because the results using this model are far more supportive of the social cleavage approach, I do not present this model here. Results from this alternative model and the model diagram itself can be found in the Supplementary Material section.
} 
To deal with this endogeneity problem, this paper proposes a simple solution: before including the social cleavage variables in the same model as the more proximate determinants of vote choice, their shared variance needs to be removed. This technique is similar to instrumental variables approaches: instead of generating new variables created from the values predicted by the social cleavages as instrumental variables approaches do, this technique generates new variables from that variance which is not predicted by the social cleavage variables (i.e. the residual values). ${ }^{9}$ This removes the variance from the more proximate vote choice determinants that is attributable to the social cleavage variables. Such a technique eliminates the need for exogenous instruments - which are not readily available for each endogenous variable in the CSES data set. Once this is done, the three residual variables representing the effects of the short-term forces variables that are independent of social cleavage effects are included alongside the variables from the vote choice equation. These models are estimated, as above, using probit regression.

\section{Analysis}

The first step in this analysis, examining the effects of the social cleavages across time periods, shows that the social cleavages have not ceased to exist. Instead, they continue to predict voting behavior significantly. Table 1 presents the results of probit models using both vote choice and party identification as dependent variables for each country in two elections: one election from the 1960s and one recent election.

\section{Table 1 about here}

Although the results differ by country, what stands out as common to all is the persistence of social cleavage effects on both dependent variables over time, in spite of

\footnotetext{
${ }^{9}$ More formally, whereas the reduced form (first stage) equation in instrumental variables approaches predicts an endogenous variable $\mathrm{y}_{\mathrm{i}}=\pi_{0}+\pi_{1} \mathrm{x}_{1}+\ldots \pi_{\mathrm{i}} \mathrm{x}_{\mathrm{i}}$, this approach predicts the residuals $\mathrm{v}_{\mathrm{i}}=\mathrm{y}_{\mathrm{i}}-\pi_{0}-\pi_{1} \mathrm{x}_{1}-\ldots \pi_{\mathrm{i}} \mathrm{x}_{\mathrm{i}}$.
} 
arguments purporting significant social dealingment. Particularly striking is the finding regarding the salience of the religious-secular cleavage: despite the sharp declines in religious observance over the past half-century (Franklin, Mackie, and Valen, 1992), the religious-secular divide remains a highly salient electoral cleavage in all three countries.

While there is some evidence of dealignment in Table 1 when examining the explanatory power of social cleavages on vote choice, the reduction in explanatory power is not as substantial as the literature would suggest for either the United States or Germany, and the pseudo $\mathrm{R}^{2}$ actually increases for Great Britain. With regard to party identification, the explanatory power of the social cleavages increases for both the United States and Great Britain; only Germany sees a reduction in explanatory power. These results suggest that while there has been considerable partisan and social dealignment among Western electorates following the Second World War, social identities still play a significant part in determining partisan identification (for those who still identify with political parties) in addition to vote choice.

Turning to the magnitudes of the effects of the social cleavages in general and religioussecular divisions in particular, Table 2 presents the predicted probability changes for a one standard deviation change in each independent variable. All nominal variables are held at their modal values; all other variables are held at their means.

\section{Table 2 about here}

The results in Table 2 suggest that in terms of the magnitude of religious-secular effects, there is little evidence of dealignment; only Germany provides evidence of this, and this dealignment effect is most pronounced with regard to vote choice and less so for party identification. ${ }^{10}$ Comparing the magnitude of religiosity effects across countries, even though there is a considerable drop in the effect of the religious-secular cleavage in Germany, the

\footnotetext{
${ }^{10}$ The 2002 German data show that this effect on vote choice is much stronger. See the Supplementary Material.
} 
magnitude of this effect on party identification in 1998 is comparable to that of the United States, in which much has been made about the increased salience of religiosity effects in the past few decades. In both the United States and Great Britain, the effect of religiosity has remained constant for both vote choice and party identification, and has not decreased as the literature suggests. Comparing the effects of religiosity to the other variables listed in Table 2, the effect of the religious-secular cleavage is similar in magnitude to those variables associated with class and status, as well as religious denominational effects. All things considered, the evidence shows that the effect of the religious-secular cleavage has remained relatively stable and important to determining vote choice over time.

Having confirmed that the religious-secular cleavage remains an important determinant in predicting individual vote choice and party identification in the first stage of the analysis, the next step is to determine whether religiosity is an important determinant of the vote through its indirect effects, namely through the short-term effects suggested by the literature to be more proximate to determining vote choice. Table 3 presents the results of regressions of these shortterm forces on the social cleavages.

\section{Table 3 about here}

As Table 3 shows, the more proximate determinants of vote choice are predicted in part by social cleavages, indicating that these variables are in fact endogenous. ${ }^{11}$ Therefore, social cleavage effects have not been displaced by short-term forces; rather, it appears that the social cleavages affect vote choice indirectly through the more proximate determinants of vote choice

\footnotetext{
${ }^{11}$ This is confirmed by Hausman tests for endogeneity (Hausman, 1978). These tests determine whether the variables of interest are endogenous by predicting residuals from the reduced form equations (as in Table 3), then using the residuals as variables in the structural equations (in this case, the probit models presented in Table 4) and dropping the exogenous (social cleavage) variables. If the coefficients for the residual variables are statistically different from zero when included alongside the hypothesized endogenous variables, then the variables of interest are endogenous. In each case, the coefficients for the residual variables are statistically significant, indicating that the three short-term forces are indeed endogenous. Thus, including the social cleavage variables without eliminating the variance shared with the short-term forces would result in type II errors regarding social cleavage effects.
} 
as the Michigan model suggests. In all but one instance, regarding economic evaluations in the United States, ${ }^{12}$ religiosity has a significant effect on the three short-term factors. Thus, these results suggest that by incorporating both short-term forces and social cleavages into the same model would result in type-II errors with regard to social cleavage effects.

The suspicion of type-II errors is confirmed in Table 4. Table 4 presents the changes in probabilities for a one standard deviation increase in the independent variables. The probabilities in the first column for each country are from probit models including all variables without dealing with endogeneity, while the values in column two are from models in which the variance shared between the three more proximate determinants of vote choice and the social cleavages is removed; parameter estimates for each model are presented in the Supplementary Material. As Table 4 shows, the probabilities for the social cleavage variables in column one appear to be underestimated for each country when the problem of endogeneity in the more proximate variables is not dealt with. This is particularly problematic for the frequency of attendance measure, which is underestimated by two-thirds in the United States, while the probability in Great Britain and Germany is only a tiny fraction of its actual magnitude.

\section{Table 4 about here}

Looking at the probabilities corrected for endogeneity in column two reveal that the religious-secular cleavage has a sizable impact on vote choice, both in relation to the other social cleavages and in relation to the more proximate determinants of vote choice. In the United States, frequency of attendance has the largest effect on vote choice out of all the social cleavage variables. While the effect of religiosity is not as large in relation to the other variables in

\footnotetext{
${ }^{12}$ One possibility for the finding of significant religiosity effects in Britain and Germany but not in the United States could be due to the use of OLS. Because this dependent variable is a five-point scale, one could argue that OLS is not the appropriate technique (the consequence being significant underestimation of the standard errors). Using an ordered probit model, however, demonstrates that this is not the case: the results are nearly identical, thus justifying the use of the simpler OLS model for the sake of comparison.
} 
Germany and Britain, it is still sizable, a finding which is remarkable given the dominant role of the class cleavage in British politics (Alford, 1963; Butler and Stokes, 1975). Even in comparison to the three short-term factors that scholars argue have displaced social cleavages as the most important determinants of vote choice, the magnitudes of the religiosity effects on vote choice are not as small as one would expect. In some cases, the effect of religiosity is roughly on par with- or even greater than some of the individual short-term effects. These results demonstrate that, in addition to the findings from the first part of the analysis showing that religiosity effects have not disappeared over time, religiosity has sizable effects on vote choice in relation to other important cleavages as well as the short-term forces argued to have displaced social cleavage effects.

\section{Discussion}

Similar to the conclusions of one fairly recent review essay regarding the persistence of class effects on voting (Evans, 2000), this essay concludes that the same can be said with regard to the religious-secular cleavage. As the data show, religious-secular effects have not evaporated over time. Instead, there appears to be an enormous degree of persistence: religious voters today continue to support parties of the right much as they did in the 1960s, both in terms of vote choice and party identification. Curiously enough, the effects of the religious-secular cleavage in each country examined here are comparable in size to the effects of the variables associated with class and status, which also remain sizable.

Furthermore, this essay contributes to the literature by showing that previous works have not properly dealt with issues of causal structure in determining the effects of social cleavage variables over time. While theory suggests that social cleavage variables are at the beginning of the causal chain (or funnel: Lewis-Beck et al., 2008: 23; Dalton 2006: 178) and therefore have 
indirect effects on vote choice that are mediated by more proximate, short-term factors, few scholars have properly addressed these issues of endogeneity. This often leads researchers to conclude that social cleavages no longer have significant effects on vote choice when in fact they do. Once these issues of endogeneity are addressed, social cleavage effects continue to play a significant role in determining vote choice.

While these conclusions are not ignorant of the fact that the net contribution of religious voters to parties of the right has declined over time as the number of religiously adherent voters have declined (Best, forthcoming; Franklin, Mackie, and Valen, 1992), the results presented here demonstrate that social cleavages (religion in particular) still matter, and therefore the study of these cleavages warrants continued research. Regardless of one's views toward the process of secularization, ${ }^{13}$ religion still matters for a sizable number of people (Greeley, 2003); for those to whom religion still matters in private, the data presented here demonstrate that religion still matters for their political behavior as well, affecting not just vote choices and party identifications but other important attitudes and behaviors that also predict vote choice.

In conclusion, future research needs to move beyond questions of whether or not religiosity (and other social cleavages) still matters for politics and instead move toward answering questions of for what (else) religiosity matters and why. Particularly important are the electoral connections between voters and parties: while some have explored the impact of parties' positions on the effects of social cleavages on party support (Elff, 2009), have religious voters' electoral demands been met on issues most important to them, or has the failure to address these voters' concerns led to the apparent partisan dealignment (visible among German voters in the data presented here)? These answers remain to be seen in future research.

\footnotetext{
${ }^{13}$ Norris and Inglehart (2004) defend secularization theory, though many scholars like Stark (1999) and Greeley (2003) have presented convincing evidence and forceful arguments that contradict many of the tenets and expectations of secularization theory.
} 


\section{Appendix}

\section{Measurement of Dependent Variables}

Vote Choice

Dummy variable coded 1 for the CDU/CSU in Germany, the Republicans in the United States, and the Conservatives in Great Britain, and 0 otherwise. Those who did not vote are excluded. This refers to the Zweitstimme (party vote) in Germany, the presidential vote in the United States, and general election vote in Great Britain.

\section{Party Identification}

Dummy variable coded 1 for the CDU/CSU in Germany, the Republicans in the United States, and the Conservatives in Great Britain, and 0 otherwise, including those with no party preference.

\section{Left-Right Self-Placement}

This variable is an 11-point measure of respondents' self-placement along a left-right ideology scale where 0 represents the left and 10 represents the right.

\section{Party Leader Preference}

This variable is an 11-point measure of respondents' ratings of the leaders of the same conservative parties as above, where 0 means the respondent strongly dislikes the party leader and 10 means the respondent strongly favors the party leader. In the United States, the party leader is the Republican presidential candidate.

\section{Economic Performance}

This question ask respondents, "What do you think about the state of the economy these days in [country]? Would you say that the state of the economy is very good, good, neither good nor bad, bad, or very bad?" I use the same 1 to 5 scale (very good to very bad) used by the CSES.

\section{Measurement of Independent Variables}

\section{Frequency of Church Attendance}

This variable ranges from 0 to 3 , with 0 referring to those who never or practically never attend services and 3 represents weekly or more-than-weekly attendance. This involves recoding frequency of attendance variables in the CSES, GES, and Political Change in Britain Survey. See Table 5 for details on how this variable is recoded with respect to each of the surveys.

\section{Denominational Differences}

Dummy variable coded 1 for the religious denomination most likely to support the party of the right, 0 otherwise. In this research, the denominations coded as 1 are Protestants in the United States, Catholics in Germany, and Anglicans in Great Britain. Protestants in the United States include Adventists, Congregationalists, Baptists, Anabaptists, Methodists, Lutherans, Unitarians, Pentecostals, Episcopalians, Presbyterians, Holiness, and those identifying as "Protestant" without reference to a specific denomination. 


\section{Union Membership}

Dummy variable coded 1 for respondents who are union members, 0 otherwise.

Income

This variable divides respondents' incomes into quintiles, where 1 represents the lowest income quintile and 5 the highest. For those surveys that use income scales with more than 5 categories, respondents were recoded into quintiles. This recoding is done for the 1960 ANES (in which the original variable was a 10-point measure), the 1965 GES (in which the original variable was an 11-point measure), and the 1964 Butler and Stokes Political Change in Britain Survey (in which the original measure was a 13-point measure). For all studies but the 1965 GES and the 1964 Butler and Stokes Political Change in Britain Survey, the variable measures household incomes. While the GES and the Political Change in Britain Survey both use head of household incomes, this does not render the measures invalid because female work force participation during this period was significantly lower than the present day.

\section{University Degree}

Dummy variable coded 1 for respondents who have attained a four-year university degree, 0 otherwise.

\section{Gender}

Dummy variable coded 1 for women, 0 otherwise.

\section{Regional Differences}

Dummy variable coded 1 for respondents who reside in the region of interest, 0 for the rest of the country. The region of interest in Great Britain is Scotland. For the United States, the region of interest is the south, including the eleven states of the former Confederacy plus Delaware, Kentucky, Oklahoma, West Virginia, and Washington, D.C.

\section{$\underline{\text { Urban }}$}

Dummy variable coded 1 for urban residents, 0 otherwise. The data from the CSES all use the same definition for what constitutes a large city or town. In the 1965 GES and the 1960 ANES, respondents are coded as urban if they reside in cities with populations of 100,000 or more. This variable is missing in the 1997 data for Britain and therefore is not used in the 1964 data as well.

\section{African American}

Dummy variable coded 1 for United States respondents who self-identify as racially black, 0 otherwise. 


\section{References}

Alford, R.R., 1963. Party and Society: The Anglo-American Democracies. Murray, London.

American National Election Study. 1960. Ann Arbor: University of Michigan. At www.icpsr@umich.edu.

Ang, A. U-J. and Petrocik, J.R., Unpublished Results. "Religion, religiosity, and the moral divide in Canadian politics." Paper presented at the Annual Conference of the Midwest Political Science Association, Chicago.

Arzheimer, K., 2006. “'Dead men walking?' Party identification in Germany, 1977-2002.” Electoral Studies 25 (4): 791-807.

Bartle, J., 1998. "Left-right position matters, but does social class? Causal models of the 1992 British general election.” British Journal of Political Science 28 (3): 501-529.

Bartolini, S. and Mair, P., 1990. Identity, Competition, and Electoral Availability: The Stabilisation of European Electorates, 1885-1985. Cambridge University Press, New York.

Bennie, L., Brand, J., and Mitchell, J. 1997. How Scotland Votes. Manchester University Press, Manchester.

Berelson, B.R., Lazarsfeld, P.R., and McPhee, W.N., 1954. Voting: A Study of Opinion Formation in a Presidential Campaign. University of Chicago Press, Chicago.

Best, R.E.. "The declining electoral relevance of traditional cleavage groups." European Political Science Review.

Black, E. and Black, M. 1987. Politics and Society in the South. Harvard University Press, Cambridge, MA.

Brooks, C. and Manza, J., 1997. "The social and ideological bases of middle-class political realignment in the United States, 1972-1992.” American Sociological Review 62 (2): 191-208.

Butler, D. and Stokes, D., 1975. Political Change in Britain (Second Edition). St. Martin's Press, New York.

Campbell, D., 2004. “Acts of faith: churches and political engagement.” Political Behavior 26 (2): $155-180$

Chan, T.W. and Goldthorpe, J.H., 2007. "Class and status: the conceptual distinction and its empirical relevance.” American Sociological Review 72 (4): 512-532. 
Comparative Study of Electoral Systems, The. 2003. Ann Arbor: University of Michigan. At www.cses.org.

Daalder, H. and Mair, P. (Eds.), 1983. Western Party Systems: Continuity and Change. Sage Publications, London.

Dalton, R.J., 1996. "Political cleavages, issues, and electoral change.” In: Leduc, L., Niemi, R., Norris, P. (Eds.), Comparing Democracies: Elections and Voting in Global Perspective. Sage Publications, Thousand Oaks, pp. 319-342.

Dalton, R.J., 2000. “The decline of party identifications.” In: Dalton, R.J., Wattenberg, M.P. (Eds.), Parties without Partisans: Political Change in Advanced Industrial Democracies. Oxford University Press, Oxford, pp. 19-36.

Dalton, R.J., 2006. Citizen Politics: Public Opinion and Political Parties in Advanced Industrial Democracies (Fourth Edition). CQ Press, Washington, D.C.

Dalton, R., Flanagan, S., and Beck, P.A. (Eds.), 1984. Electoral Change in Advanced Industrial Democracies, (Fourth Edition). CQ Press, Washington, D.C.

Dalton, R, McAllister, I., and Wattenberg, M.P., 2000. "The consequences of partisan dealignment.” In: Dalton, R.J., Wattenberg, M.P. (Eds.), Parties without Partisans: Political Change in Advanced Industrial Democracies. Oxford University Press, Oxford, pp. 37-63.

De Koster, W. and Van Der Waal, J., 2007. "Cultural value orientations and Christian religiosity: on moral traditionalism, authoritarianism, and their implications for voting behavior." International Political Science Review 28 (4): 451-467.

De Witte, H. and Billiet, J., 1999. "Economic and cultural conservatism in Flanders: in search of concepts, determinants and impact on voting behavior." In De Witte, H., Scheepers, P. (Eds.) Ideology in the Low Countries: Trends, Models, and Lacunae. Van Gorcum, Assen, pp. 91-121.

Djupe, P.A., 2000. "Religious brand loyalty and political loyalties." Journal for the Scientific Study of Religion 39 (1): 78-89.

Elff, M., 2007. "Social structure and electoral behavior in comparative perspective: the decline of social cleavages in Western Europe revisited." Perspectives on Politics 5 (2): 277-294.

Elff, M., 2009. "Social divisions, party positions, and electoral behaviour." Electoral Studies 28 (2): $1-12$.

Evans, G. 2000. "The continued significance of class voting." Annual Review of Political Science 3: 401-417. 
Fiorina, M. P. 1981. Retrospective Voting in American National Elections. Yale University Press, New Haven.

Franklin, M.N., 1985. The Decline of Class Voting. Clarendon Press, Oxford.

Franklin, M.N., Mackie, T.T., and Valen, H. (Eds.), 1992. Electoral Change: Responses to Evolving Social and Attitudinal Structures in Western Countries. Cambridge University Press, Cambridge.

Gaskins, B., Golder, M., and Siegel, D., Unpublished results. "Religiosity, societal development, and political attitudes." Paper Presented at the Annual Conference of the Midwestern Political Science Association, Chicago.

German Election Study (October). 1965. Ann Arbor: University of Michigan. At www.icpsr@umich.edu.

Gerteis, J. and Savage, M., 1998. "The salience of class in Britain and America: a comparative analysis.” The British Journal of Sociology 49 (2): 252-274.

Greeley, A. 2003. Religion in Europe at the End of the Second Millennium. Transaction Publishers, New Brunswick, New Jersey.

Green, J.C. and Guth, J.L., 1993. "From lambs to sheep: denominational change and political behavior.” In: Leege, D.C., Kellstedt, L.A., et al. (Eds), Rediscovering the Religious Factor in American Politics. M.E. Sharpe, Armonk, pp. 100-120.

Hammond, P.E., Shibley, M.A., and Solow, P.M., 1994. "Religion and family values in presidential voting." Sociology of Religion 55 (3): 277-290.

Hausman, J.A. 1978. "Specification tests in econometrics." Econometrica 46 (6): 1251-1271.

Heath, A., Jowell, R., Curtice, J., Evans, G., Field, J., and Witherspoon, S., 1991. Understanding Political Change: The British Voter 1964-1987. Pergamon Press, New York.

Hout, M. and Fischer, C.S., 2002. "Why more Americans have no religious preference: politics and generations.” American Sociological Review 67 (2): 165-190.

Inglehart, R., 1977. The Silent Revolution: Changing Values and Political Styles among Western Publics. Princeton University Press, Princeton.

Inglehart, R., 1984. "The changing structure of political cleavages in Western society." In: Dalton, R. J., Flanagan, S., Beck, P. A. (Eds.), Electoral Change in Advanced Industrial Democracies. Princeton University Press, Princeton, pp. 25-69.

Inglehart, R., 1997. Modernization and Postmodernization: Cultural, Economic, and Political Change in 43 Societies. Princeton University Press, Princeton. 
Inglehart, R. and Klingemann, H.-D., 1976. "Party identification, ideological preference and leftright dimension.” In: Budge, I., Crewe, I., Farlie, D., (Eds.), Party Identification and Beyond. John Wiley \& Sons, London, pp. 243-273.

Jagodzinski, W. and Kühnel, S.M., 1998. "The stability of the meaning of left and right in Germany, 1976-90.” In: Anderson, C.J., Zelle, C. (Eds.), Stability and Change in German Elections: How Electorates Merge, Converge, or Collide. Praeger, Westport, pp. 121-152.

Johnson, S.D., 1994. "What relates to vote for three religious categories?" Sociology of Religion 55 (3): 263-275.

Knutsen, O., 1988. "The impact of structural and ideological party cleavages in ten Western European countries - a comparative empirical analysis." British Journal of Political Science 18 (3): 323-352.

Knutsen, O., 2004. Social Structure and Party Choice: A Comparative Longitudinal Study. Palgrave Macmillan, New York.

Knutsen, O., 2006. Class Voting in Western Europe: A Comparative Longitudinal Study. Lexington Books, New York.

Kotler-Berkowitz, L. A. 2001. "Religion and voting behavior in Great Britain: a reassessment." British Journal of Political Science 31 (3): 523-554.

Lane, J.-E. and Ersson, S., 1999. Politics and Society in Western Europe (Fourth Edition). Sage Publications, Thousand Oaks.

Layman, G. 2001. The Great Divide: Religious and Cultural Conflict in American Party Politics. Columbia University Press, New York.

Layman, G. and Carmines, E.G., 1997. "Cultural conflict in American politics: religious traditionalism, postmaterialism, and US political behavior.” Journal of Politics 59 (3): 751-777.

Lewis-Beck, M., 1988. Economics and Elections: The Major Western Democracies. University of Michigan Press, Ann Arbor.

Lewis-Beck, M., Jacoby, W. G., Norpoth, H. and Weisberg, H. F. 2008. The American Voter Revisited. University of Michigan Press, Ann Arbor.

Lipset, S.M., 2001. "The Americanization and the European left," In: Diamond, L. and Gunther, R. (Eds.), Political Parties and Democracy. Johns Hopkins University Press, Baltimore. 
Lipset, S.M. and Rokkan, S., 1967. "Cleavage structures, party systems, and voter alignments: an introduction,” In: Lipset, S.M., Rokkan, S. (Eds.), Party Systems and Voter Alignments: Cross-national Perspectives. Free Press, New York, pp. 1-67.

Manza, J., Hout, M., and Brooks, C., 1995. "Class voting in capitalist democracies since World War II: dealignment, realignment, or trendless fluctuation?” Annual Review of Sociology 21: $137-162$.

Mulligan, K., 2008. “The 'myth' of moral values voting in the 2004 presidential election.” PS: Political Science and Politics 41 (1): 109-114.

Norris, P., 1997. Electoral Change since 1945. Blackwell Publishers, Cambridge.

Norris, P. and Inglehart, R., 2004. Sacred and Secular: Religion and Politics Worldwide. Cambridge University Press, New York.

Oesch, D., 2008. "Explaining workers' support for right-wing populist parties in Western Europe: evidence from Austria, Belgium, France, Norway, and Switzerland." International Political Science Review 29 (3): 329-373.

Pederson, M., 1983. "Changing patterns of electoral volatility in European party systems, 194877.” In: Daalder, H., Mair, P. (Eds.), Western European Party Systems: Continuity and Change. Sage Publications, London, pp. 29-66.

Petrocik, J.R., 1987. "Realignment: new party coalitions and the nationalization of the south." Journal of Politics 49 (2): 347-375.

Petrocik, J.R., 1996. "Issue ownership in presidential elections, with a 1980 case study." American Journal of Political Science 40 (3): 825-850.

Petrocik, J.R., Unpublished results. "Reformulating the party coalitions: the 'Christian Democratic' Republicans." Paper presented at the Annual Meeting of the American Political Science Association, Boston.

Political Change in Britain, 1963-1970. 1979. Ann Arbor: University of Michigan. At www.icpsr@umich.edu.

Powell, G.B., Jr., 1986. “American voter turnout in comparative perspective.” American Journal of Political Science 80 (1): 17-44.

Prandy, K., 2000. "Class, the stratification order, and party identification." British Journal of Political Science 30 (2): 237-258.

Robertson, D., 1984. Class and the British Electorate. Basil Blackwell, Oxford.

Rose, R., (Ed.), 1974. Electoral Behavior: A Comparative Handbook. Free Press, New York. 
Rose, R. and McAllister, I., 1990. The Loyalties of Voters. Sage Publications, New York.

Rose, R. and Urwin, D., 1969. "Social cohesion, political parties and strains in regimes." Comparative Political Studies 2 (1): 7-67.

Schmitt, K., 1998. "The social bases of voting behavior in unified Germany.” In: Anderson, C.J., Zelle, C. (Eds.), Stability and Change in German Elections: How Electorates Merge, Converge, or Collide. Praeger, Westport, pp. 33-54.

Schoen, H., 2007. "Campaigns, candidate evaluations, and vote choice: evidence from German federal election campaigns, 1980-2002." Electoral Studies 26 (2): 324-337.

Stark, R. 1999. “Secularization, R.I.P.” Sociology of Religion 60 (3): 249-273.

van der Waal, J., Achterberg, P., and Houtman, D., 2007. "Class is not dead it has been buried alive: class voting and cultural voting in postwar western societies." Politics and Society 35 (3): 403-426.

Verba, S., Schlozman, K.L., and Brady, H.E., 1995. Voice and Equality: Civic Voluntarism in American Politics. Harvard University Press, Cambridge.

Vetter, A. and Gabriel, O.W., 1998. "Candidate evaluations and party choice in Germany, 197294: do candidates matter?" In: Anderson, C.J., Zelle, C. (Eds.), Stability and Change in German Elections: How Electorates Merge, Converge, or Collide. Praeger, Westport, pp. 71-98.

Veugelers, J.W.P., 2000. "Right-wing extremism in contemporary France: a 'silent counterrevolution'?" The Sociological Quarterly 41 (1): 19-40.

Wald, K., 1983. Crosses on the Ballot: Patterns of British Voter Alignments since 1885. Princeton University Press, Princeton.

Wald, K, Owen, D.E., and Hill, Jr., S.S., 1988. "Churches as political communities.” American Political Science Review 82 (2): 531-548.

Weakliem, D., 1995. “Two models of class voting.” British Journal of Political Science 25 (2): 254-270.

Zelle, C, 1998. "A third force of dealignment? An update on party identification in Germany, 1976-90." In: Anderson, C.J., Zelle, C. (Eds.), Stability and Change in German Elections: How Electorates Merge, Converge, or Collide. Praeger, Westport, pp. 55-70. 
Figure 1 Path Model of the Effects of Social Cleavages on Vote Choice

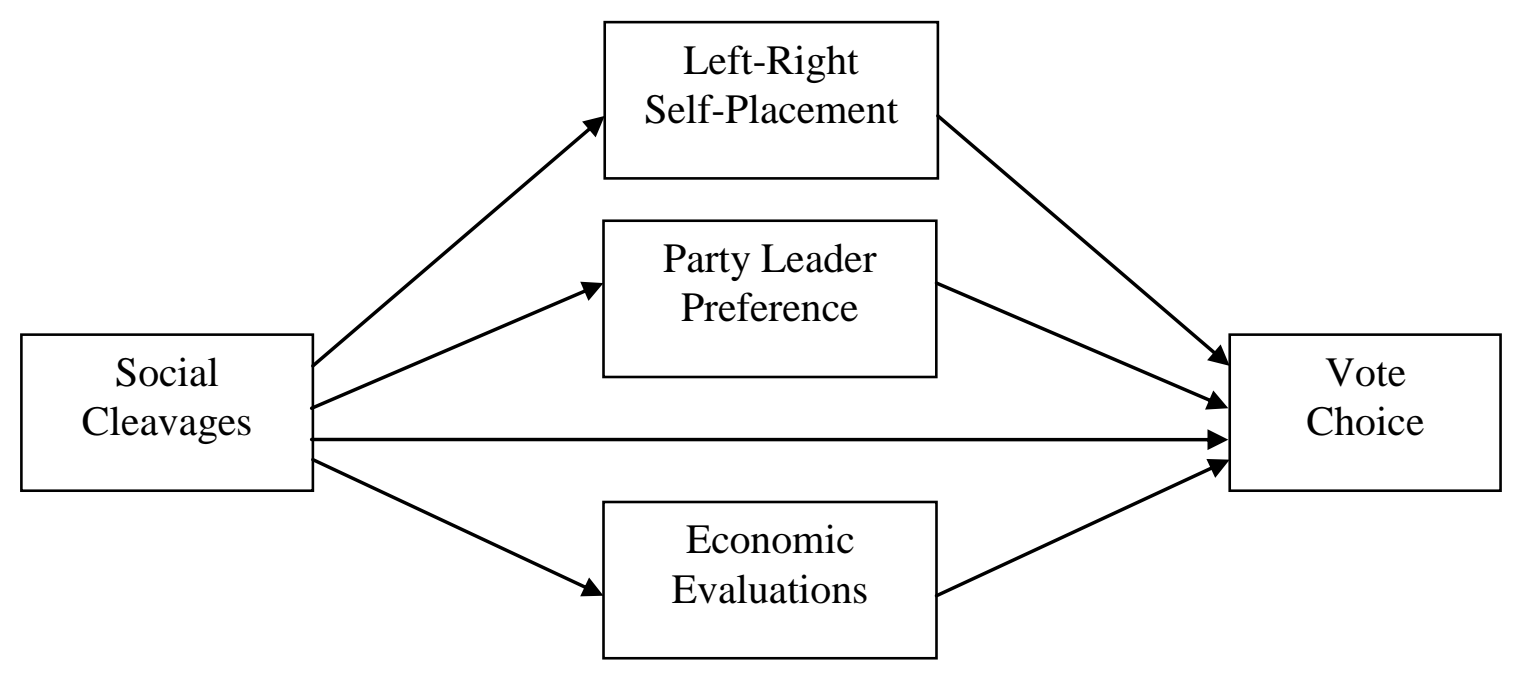


Tables

\begin{tabular}{|c|c|c|c|c|c|c|}
\hline \multicolumn{7}{|c|}{$\begin{array}{l}\text { Table } 1 \text { Effects of Social Cleavages on Conservative Party Vote Choice } \\
\text { (Maximum Likelihood Probit Coefficients) }\end{array}$} \\
\hline $\begin{array}{c}\text { DV: } \\
\text { Vote Choice }\end{array}$ & UK 1964 & UK 1997 & US 1960 & US 1996 & GER 1965 & GER 1998 \\
\hline Attendance & $\begin{array}{l}.091 * \\
(.032) \\
\end{array}$ & $\begin{array}{l}.108 * * \\
(.027) \\
\end{array}$ & $\begin{array}{l}.177 * * \\
(.046) \\
\end{array}$ & $\begin{array}{l}.234 * * \\
(.038) \\
\end{array}$ & $\begin{array}{l}.367 * * \\
(.045) \\
\end{array}$ & $\begin{array}{l}.143 * \\
(.052) \\
\end{array}$ \\
\hline $\begin{array}{c}\text { Religious } \\
\text { Denomination }\end{array}$ & $\begin{array}{l}.379 * * \\
(.091) \\
\end{array}$ & $\begin{array}{l}.461 * * \\
(.069) \\
\end{array}$ & $\begin{array}{c}1.486 * * \\
(.123)\end{array}$ & $\begin{array}{l}.423 * * \\
(.090) \\
\end{array}$ & $\begin{array}{l}.421 * * \\
(.095) \\
\end{array}$ & $\begin{array}{l}.447 * * \\
(.105) \\
\end{array}$ \\
\hline $\begin{array}{c}\text { Union } \\
\text { Member }\end{array}$ & $\begin{array}{c}-.638 * * \\
(.096)\end{array}$ & $\begin{array}{l}-.502 \\
(.080) \\
\end{array}$ & $\begin{array}{l}-.280^{*} \\
(.132) \\
\end{array}$ & $\begin{array}{c}-.660 * * \\
(.136)\end{array}$ & $\begin{array}{c}-.543 * * \\
(.127)\end{array}$ & $\begin{array}{c}-.489 * * \\
(.143)\end{array}$ \\
\hline Income & $\begin{array}{l}.073 * * \\
(.012) \\
\end{array}$ & $\begin{array}{l}.201 * * \\
(.023) \\
\end{array}$ & $\begin{array}{c}.007 \\
(.040) \\
\end{array}$ & $\begin{array}{l}.189 * * \\
(.041)\end{array}$ & $\begin{array}{c}.006 \\
(.038) \\
\end{array}$ & $\begin{array}{l}.130 * * \\
(.038) \\
\end{array}$ \\
\hline $\begin{array}{l}\text { University } \\
\text { Completed }\end{array}$ & $\begin{array}{l}.364 \\
(.232)\end{array}$ & $\begin{array}{l}-.238^{*} \\
(.102)\end{array}$ & $\begin{array}{l}.274 * \\
(.117)\end{array}$ & $\begin{array}{l}.055 \\
(.095)\end{array}$ & $\begin{array}{l}.278 \\
(.238)\end{array}$ & $\begin{array}{l}-.105 \\
(.168)\end{array}$ \\
\hline $\begin{array}{l}\text { Likelihood } \\
\text { Ratio (df) }\end{array}$ & $113.75(7)$ & $229.98(7)$ & $215.57(9)$ & $216.29(9)$ & $185.66(7)$ & $68.42(7)$ \\
\hline $\begin{array}{c}\text { Pseudo } \mathrm{R}^{2} \\
(\text { Cox-Snell) }\end{array}$ & .085 & .105 & .204 & .191 & .173 & .091 \\
\hline $\mathrm{n}$ & 1283 & 2072 & 944 & 1018 & 975 & 719 \\
\hline $\begin{array}{c}\text { DV: } \\
\text { Party ID }\end{array}$ & UK 1964 & UK 1997 & US 1960 & US 1996 & GER 1965 & GER 1998 \\
\hline Attendance & $\begin{array}{l}.097 * \\
(.031)\end{array}$ & $\begin{array}{l}.167 * * \\
(.036)\end{array}$ & $\begin{array}{l}.147 * \\
(.047)\end{array}$ & $\begin{array}{l}.241 * * \\
(.043)\end{array}$ & $\begin{array}{l}.307 * * \\
(.042)\end{array}$ & $\begin{array}{l}.261 * * \\
(.078)\end{array}$ \\
\hline $\begin{array}{c}\text { Religious } \\
\text { Denomination }\end{array}$ & $.420 * *$ & $\begin{array}{l}.508 * * \\
(.090)\end{array}$ & $\begin{array}{c}1.006 * * \\
(.126) \\
\end{array}$ & $\begin{array}{l}.557 * * \\
(.105) \\
\end{array}$ & $\begin{array}{l}.376^{* * *} \\
(.088)\end{array}$ & $\begin{array}{r}.263 \\
(.161) \\
\end{array}$ \\
\hline $\begin{array}{c}\text { Union } \\
\text { Member }\end{array}$ & $\begin{array}{c}-.574 * * \\
(.091)\end{array}$ & $\begin{array}{c}-.834 * * \\
(.107)\end{array}$ & $\begin{array}{c}-.287 \\
(.141) \\
\end{array}$ & $\begin{array}{c}-.843 * * \\
(.168)\end{array}$ & $\begin{array}{c}-.407 * * \\
(.121)\end{array}$ & $\begin{array}{l}-.477 * \\
(.197) \\
\end{array}$ \\
\hline Income & $\begin{array}{l}.058 * * \\
(.012)\end{array}$ & $\begin{array}{l}.267 * * \\
(.030)\end{array}$ & $\begin{array}{l}-.075 \\
(.040) \\
\end{array}$ & $\begin{array}{l}.264 * * \\
(.045) \\
\end{array}$ & $\begin{array}{c}.031 \\
(.035) \\
\end{array}$ & $\begin{array}{c}.105 \\
(.058) \\
\end{array}$ \\
\hline $\begin{array}{l}\text { University } \\
\text { Completed }\end{array}$ & $\begin{array}{r}.409 \\
(.221) \\
\end{array}$ & $\begin{array}{r}-.383^{*} \\
(.135) \\
\end{array}$ & $\begin{array}{l}.296 * \\
(.115) \\
\end{array}$ & $\begin{array}{r}.024 \\
(.112) \\
\end{array}$ & $\begin{array}{r}.227 \\
(.219) \\
\end{array}$ & $\begin{array}{r}.115 \\
(.221) \\
\end{array}$ \\
\hline $\begin{array}{l}\text { Likelihood } \\
\text { Ratio (df) }\end{array}$ & $111.66(7)$ & $223.12(7)$ & $146.35(9)$ & $235.01(9)$ & $145.58(7)$ & $32.00(7)$ \\
\hline $\begin{array}{c}\text { Pseudo R } \\
\text { (Cox-Snell) }\end{array}$ & .075 & .172 & .140 & .256 & .126 & .097 \\
\hline $\mathrm{n}$ & 1428 & 1180 & 968 & 793 & 1082 & 314 \\
\hline
\end{tabular}

* Significant at the .05 level. ** Significant at the .001 level. The values presented are probit coefficients presented above their standard errors in parentheses. Only select coefficients are presented in the interest of space. 


\begin{tabular}{|c|c|c|c|c|c|c|}
\hline \multicolumn{7}{|c|}{$\begin{array}{l}\text { Table } 2 \text { Changes in Probability } \\
\text { (Based on Results in Table 1) }\end{array}$} \\
\hline $\begin{array}{c}\text { DV: } \\
\text { Vote Choice }\end{array}$ & UK 1964 & UK 1997 & US 1960 & US 1996 & GER 1965 & GER 1998 \\
\hline Attendance & 3.91 & 4.14 & 6.06 & 11.13 & 16.02 & 5.04 \\
\hline $\begin{array}{c}\text { Religious } \\
\text { Denomination }\end{array}$ & 6.37 & 7.18 & 21.72 & 8.39 & 8.31 & 7.43 \\
\hline $\begin{array}{l}\text { Union } \\
\text { Member }\end{array}$ & -9.82 & -7.02 & -3.44 & -9.19 & -7.87 & -6.43 \\
\hline Income & 7.97 & 9.31 & 0.31 & 9.06 & 0.27 & 5.96 \\
\hline $\begin{array}{l}\text { University } \\
\text { Completed }\end{array}$ & 2.09 & -2.52 & 3.95 & 1.03 & 2.05 & -1.11 \\
\hline $\begin{array}{c}\text { DV: } \\
\text { Party ID }\end{array}$ & UK 1964 & UK 1997 & US 1960 & US 1996 & GER 1965 & GER 1998 \\
\hline Attendance & 4.13 & 6.89 & 5.80 & 10.72 & 13.07 & 9.56 \\
\hline $\begin{array}{c}\text { Religious } \\
\text { Denomination }\end{array}$ & 7.05 & 8.67 & 16.79 & 10.24 & 7.22 & 4.46 \\
\hline $\begin{array}{l}\text { Union } \\
\text { Member }\end{array}$ & -8.84 & -12.81 & -4.05 & -10.24 & -5.65 & -6.88 \\
\hline Income & 6.28 & 13.77 & -3.76 & 12.28 & 1.40 & 4.93 \\
\hline $\begin{array}{l}\text { University } \\
\text { Completed }\end{array}$ & 2.28 & -4.46 & 4.89 & 0.42 & 1.66 & 1.40 \\
\hline
\end{tabular}

Values represent the change in probability resulting from a one-standard deviation increase in the respective independent variables. Probabilities are for selected variables only. 


\begin{tabular}{|c|c|c|c|c|c|c|}
\hline \multicolumn{7}{|c|}{$\begin{array}{l}\text { Table } 3 \text { Effects of Social Cleavages on More Proximal Vote Determinants } \\
\text { (OLS Regression Coefficients) }\end{array}$} \\
\hline UK 1997 & Religiosity & $\begin{array}{l}\text { Denomin- } \\
\text { ation }\end{array}$ & $\begin{array}{l}\text { Union } \\
\text { Member }\end{array}$ & Income & $\begin{array}{l}\text { University } \\
\text { Education }\end{array}$ & $\begin{array}{l}\text { Adjusted } \\
\mathrm{R}^{2}\end{array}$ \\
\hline $\begin{array}{l}\text { Left-Right Self- } \\
\text { Placement }\end{array}$ & $\begin{array}{l}.205 * * \\
(.044)\end{array}$ & $\begin{array}{l}.661 * * \\
(.109)\end{array}$ & $\begin{array}{c}-.615 * * \\
(.107)\end{array}$ & $\begin{array}{l}.120 * * \\
(.036)\end{array}$ & $\begin{array}{l}-.696 * * \\
(.138) \\
\end{array}$ & .058 \\
\hline $\begin{array}{l}\text { Party Leader } \\
\text { Preference }\end{array}$ & $\begin{array}{l}.379 * * \\
(.054)\end{array}$ & $\begin{array}{l}.854 * * \\
(.139)\end{array}$ & $\begin{array}{c}-.686 * * \\
(.136)\end{array}$ & $\begin{array}{l}.305 * * \\
(.044)\end{array}$ & $\begin{array}{l}.218 \\
(.175)\end{array}$ & .079 \\
\hline $\begin{array}{c}\text { Economic } \\
\text { Performance }\end{array}$ & $\begin{array}{c}-.061 * * \\
(.014)\end{array}$ & $\begin{array}{c}-.235^{* *} \\
(.035)\end{array}$ & $\begin{array}{l}.174 * * \\
(.037)\end{array}$ & $\begin{array}{c}-.121 * * \\
(.012)\end{array}$ & $\begin{array}{l}-.124^{*} \\
(.049)\end{array}$ & .097 \\
\hline USA 1996 & Religiosity & $\begin{array}{l}\text { Denomin- } \\
\text { ation }\end{array}$ & $\begin{array}{l}\text { Union } \\
\text { Member }\end{array}$ & Income & $\begin{array}{l}\text { University } \\
\text { Education }\end{array}$ & $\begin{array}{c}\text { Adjusted } \\
\mathrm{R}^{2}\end{array}$ \\
\hline $\begin{array}{l}\text { Left-Right Self- } \\
\text { Placement }\end{array}$ & $\begin{array}{l}.323 * * \\
(.046)\end{array}$ & $\begin{array}{l}.309 * \\
(.114)\end{array}$ & $\begin{array}{l}-.385^{*} \\
(.162)\end{array}$ & $\begin{array}{c}.031 \\
(.048)\end{array}$ & $\begin{array}{c}-.428 * * \\
(.132)\end{array}$ & .078 \\
\hline $\begin{array}{l}\text { Party Leader } \\
\text { Preference }\end{array}$ & $\begin{array}{l}.253 * * \\
(.052)\end{array}$ & $\begin{array}{l}.609 * * \\
(.131)\end{array}$ & $\begin{array}{c}-.739 * * \\
(.173)\end{array}$ & $\begin{array}{l}.217 * * \\
(.055)\end{array}$ & $\begin{array}{l}.158 \\
(.138)\end{array}$ & .094 \\
\hline $\begin{array}{c}\text { Economic } \\
\text { Performance }\end{array}$ & $\begin{array}{l}-.013 \\
(.019) \\
\end{array}$ & $\begin{array}{c}.066 \\
(.048)\end{array}$ & $\begin{array}{l}-.032 \\
(.073)\end{array}$ & $\begin{array}{l}-.027 \\
(.022)\end{array}$ & $\begin{array}{c}-.262 * * \\
(.051)\end{array}$ & .068 \\
\hline Germany 1998 & Religiosity & $\begin{array}{l}\text { Denomin- } \\
\text { ation }\end{array}$ & $\begin{array}{l}\text { Union } \\
\text { Member }\end{array}$ & Income & $\begin{array}{l}\text { University } \\
\text { Education }\end{array}$ & $\begin{array}{c}\text { Adjusted } \\
\mathrm{R}^{2}\end{array}$ \\
\hline $\begin{array}{l}\text { Left-Right Self- } \\
\text { Placement }\end{array}$ & $\begin{array}{l}.278 * * \\
(.080)\end{array}$ & $\begin{array}{l}.291 \\
(.161)\end{array}$ & $\begin{array}{c}.262 \\
(.225)\end{array}$ & $\begin{array}{l}.127 * \\
(.057)\end{array}$ & $\begin{array}{l}-.202 \\
(.230)\end{array}$ & .033 \\
\hline $\begin{array}{l}\text { Party Leader } \\
\text { Preference }\end{array}$ & $\begin{array}{l}.550 * * \\
(.105)\end{array}$ & $\begin{array}{c}.406 \\
(.212)\end{array}$ & $\begin{array}{l}-.508^{*} \\
(.263)\end{array}$ & $\begin{array}{l}.113 \\
(.076)\end{array}$ & $\begin{array}{l}-.114 \\
(.301)\end{array}$ & .061 \\
\hline $\begin{array}{c}\text { Economic } \\
\text { Performance }\end{array}$ & $\begin{array}{c}-.168 * * \\
(.048)\end{array}$ & $\begin{array}{l}-.069 \\
(.099)\end{array}$ & $\begin{array}{l}.158 \\
(.120)\end{array}$ & $\begin{array}{l}-.069^{*} \\
(.035)\end{array}$ & $\begin{array}{l}-.331 * \\
(.155)\end{array}$ & .056 \\
\hline
\end{tabular}

* Significant at the .05 level. ** Significant at the .001 level. The values presented are unstandardized regression coefficients presented above their standard errors in parentheses. Only select coefficients are presented in the interest of space. 


\begin{tabular}{|c|c|c|c|c|c|c|}
\hline \multicolumn{7}{|c|}{ Table 4 Changes in Probabilities of Vote Choice } \\
\hline & \multicolumn{2}{|c|}{ UK 1997 } & \multicolumn{2}{c|}{ US 1996 } & \multicolumn{2}{c|}{ GER 1998 } \\
\cline { 2 - 7 } & 1 & 2 & 1 & 2 & 1 & 2 \\
\hline Left-Right Self-Placement & 16.12 & 14.15 & 18.76 & 18.68 & 12.16 & 11.39 \\
\hline Party Leader Preference & 18.39 & 16.08 & 46.68 & 46.07 & 20.16 & 18.66 \\
\hline Economic Evaluations & -10.21 & -8.79 & 9.38 & 9.50 & -4.07 & -3.74 \\
\hline Attendance & 0.66 & 5.27 & 5.64 & 15.84 & -0.21 & 5.80 \\
\hline Religious Denomination & 3.90 & 8.97 & 3.88 & 12.47 & 6.23 & 8.19 \\
\hline Union Member & -3.16 & -7.00 & -6.15 & -13.44 & -7.17 & -7.81 \\
\hline Income & 5.86 & 10.68 & 8.73 & 14.68 & 5.53 & 7.53 \\
\hline University Completed & -2.12 & -2.55 & 4.19 & 2.67 & -1.89 & -2.10 \\
\hline
\end{tabular}

Values represent the change in probability resulting from a one-standard deviation increase in the respective independent variables. Probabilities are for selected variables only. Probabilities in column two are the result of models that eliminate the shared variance between each of the three proximate determinants of vote choice and the social cleavage variables. 


\begin{tabular}{|c|c|c|c|c|}
\hline \multirow{2}{*}{ Survey } & \multicolumn{3}{|c|}{ Table 5 Recoding Religiosity According to Each Survey } \\
\cline { 2 - 5 } & 0 & 1 & 2 & 3 \\
\hline CSES & "never" & "once a year" & $\begin{array}{c}\text { "two to eleven } \\
\text { times a year", } \\
\text { "once a month" }\end{array}$ & $\begin{array}{c}\text { "two or more } \\
\text { times a month", } \\
\text { "once a week" }\end{array}$ \\
\hline ANES & "never" & "seldom" & "often" & "regularly" \\
\hline GES & $\begin{array}{c}\text { "less often or } \\
\text { never" }\end{array}$ & $\begin{array}{c}\text { "only once a } \\
\text { year" }\end{array}$ & $\begin{array}{c}\text { "more than once } \\
\text { a year", "at least } \\
\text { once a month" }\end{array}$ & $\begin{array}{c}\text { "at least once a } \\
\text { week", "more } \\
\text { than once a } \\
\text { week" }\end{array}$ \\
\hline $\begin{array}{c}\text { Political Change } \\
\text { in Britain }\end{array}$ & $\begin{array}{c}\text { "never", "less } \\
\text { than once a year" }\end{array}$ & "once a year" & $\begin{array}{c}\text { "several } \\
\text { times/year", } \\
\text { "once a month" }\end{array}$ & $\begin{array}{c}\text { "several } \\
\text { times/month", } \\
\text { "once a week", } \\
\text { "several } \\
\text { times/week" }\end{array}$ \\
\hline
\end{tabular}

Entries are the answers respondents could give in the original surveys to the respective frequency of attendance questions. 


\section{Supplementary Material}

\section{Robustness Checks with CSES $2^{\text {nd }}$ Wave Data}

Comparing the results in Table S.1 (presented here) with Tables 1 and 2 in the text reveals that the findings using the first wave of the CSES data presented in the text are not specific to those particular elections. While there are some slight differences between Table S.1 and Tables 1 and 2, the differences are relatively minor. The most dramatic differences are between the 1996 and 2004 elections in the United States, with the magnitude of the probability changes in 1996 surpassing those of 2004. The probabilities, however, remain sizable in 2004, despite the drop from 1996. Few would argue that issues dividing religious and secular no longer matter in the United States; rather, the reason for this drop is most likely due to campaignspecific effects (consider that the 2004 election included issues surrounding U.S. involvement in Iraq) and measurement (using other measures of religiosity not utilized in the text improves the probability changes to about the same level as in 1996). In sum, the relative stability of social cleavage effects demonstrated in Tables 1,2, and S.1 provides additional evidence that the effect of the social cleavages in general (and religiosity in particular) on vote choice and party identification are far more stable than believed by the literature.

\section{Estimating the Path Model with the Addition of Party Identification}

Because the Michigan model suggests that party identification is an intervening variable between social cleavages and the more proximate short-term forces that determine vote choice, I re-ran the second stage of the analysis (Tables 3 and 4 in the text). The revised model is presented in Figure S.1. Here, the effect of social cleavages on vote choice appears entirely indirect, mediated by party identification, which in turn affects the short-term forces of left-right self-placement, party leader preference, and economic evaluations. Estimating a model with all of these variables included in the model would surely find that the social cleavage variables are insignificant.

As in the analyses performed in the text, here I also remove the variance in the endogenous variables of interest that is shared with the social cleavage variables by the same methods. The one difference is with regard to party identification. To remove the shared variance between party identification and social cleavages, I first run probit regression to estimate the linearly predicted values for party identification. I then subtract these values from the observed values for party identification in order to obtain the residuals. In theory and in practice, this differs little with regard to the final results of this technique, whether using the same model except estimating deviance residuals instead of linearly predicted residuals, or Pearson residuals predicted by a logit model. Once the residuals are calculated, I predict the residuals from the regression models predicting the other three endogenous variables representing the three short-term forces in the same way as in the text, with the inclusion of the endogeneity-corrected party identification variable. Results of select social cleavage variables on these short-term forces (comparable to Table 3 in the text), controlling for party identification, are presented in Table S.2.

The results show that, like in Table 3, the effects of the social cleavages on the short-term forces that are more proximate to vote choice remain sizable and significant. This demonstrates that, like in the results presented in the text, once the endogeneity of the relationship between 
party identification and social cleavages is accounted for, variables like religiosity have sizable and significant effects on these short-term forces variables. Furthermore, this demonstrates that these variables are endogenous and that social cleavages have indirect effects on these more proximate determinants of vote choice (though here, the results show that these effects are also indirect through party identification as well).

Table S.3 presents the predicted probability changes of voting for conservative parties for a one standard deviation change in some of the respective independent variables. The same set of select social cleavage variables is presented here as in the text and the results can be compared to Table 4. Compared with Table 4, the results in Table S.3 demonstrate that once party identification effects are removed from the short-term forces, the magnitude of these effects on vote choice are greatly diminished. Additionally, the magnitude of the social cleavage effects increases substantially. Whereas the social cleavage effects are generally smaller than the shortterm forces in Table 4, these effects are generally larger than each of the short-term forces in Table S.3. With regard to the religious-secular cleavage, this variable's effect far outweighs each of the short-term forces variables. Additionally, and similar to the results in Table 4, even after controlling for those denominations most likely to support the conservative parties, the religious-secular cleavage appears roughly equivalent in terms of the magnitude of the probability changes in the dependent variable as each of the class and status variables. Thus, the findings in Table S.3 lend even more support to the conclusions drawn from Table 4 in the text, that the religious-secular cleavage remains very salient to individual vote choice because it is a significant predictor of the more proximate determinants of vote choice.

\section{Parameter Estimates Accompanying Table 4}

Finally, I present the parameter estimates used to produce the predicted probabilities found in Table 4 in the text. Because the individual parameter estimates do not convey the results as efficiently as the predicted probabilities, I leave these parameter estimates out of the main text. Looking at these values in Table S.4 tells much the same story as in the text. Column 1 for each country presents the unadjusted results of probit models including all variables without adjusting for endogeneity, while column 2 for each country presents the results adjusted for endogeneity. Comparing columns 1 and 2 show that, like Table 4 in the text, the effects of the social cleavage variables are underestimated if endogeneity is not accounted for. While frequency of attendance remains a significant predictor of vote choice in the United States and Germany when included in the same model as the three short-term forces, the coefficients are substantially smaller than those coefficients corrected for endogeneity in column 2. What one also notices is that correcting for endogeneity does not alter the explanatory power of the model. Additionally, the coefficients for the short-term forces variables and their standard errors remain largely unchanged. This demonstrates that correcting for endogeneity does not penalize the short-term forces variables. Rather, all that correcting for endogeneity does is to attribute all variance (direct and indirect through the short-term forces variables) to the social cleavage variables. 
Table S.1 Parameter Estimates for Probit Models and Respective Changes in Probabilities with $2^{\text {nd }}$ Wave of the CSES (Similar to Tables 1 and 2 in the text)

\begin{tabular}{|c|c|c|c|}
\hline Variable & $\begin{array}{c}\mathrm{UK} \\
2005\end{array}$ & $\begin{array}{l}\text { USA } \\
2004\end{array}$ & $\begin{array}{c}\text { Germany } \\
2002\end{array}$ \\
\hline \multicolumn{4}{|l|}{ Vote Choice } \\
\hline Attendance & $\begin{array}{c}.129 * \\
(.050) \\
4.94\end{array}$ & $\begin{array}{c}.115^{*} \\
(.043) \\
5.38\end{array}$ & $\begin{array}{l}.248^{* *} \\
(.049) \\
9.38\end{array}$ \\
\hline $\begin{array}{l}\text { Religious } \\
\text { Denomination }\end{array}$ & $\begin{array}{c}.359 * \\
(.123) \\
5.76\end{array}$ & $\begin{array}{l}.386^{* *} \\
(.112) \\
7.13\end{array}$ & $\begin{array}{c}.369^{* *} \\
(.103) \\
6.46\end{array}$ \\
\hline $\begin{array}{l}\text { Union } \\
\text { Member }\end{array}$ & $\begin{array}{l}-.545^{* *} \\
(.154) \\
-7.53\end{array}$ & $\begin{array}{l}-.628 * * \\
(.168) \\
-7.41\end{array}$ & $\begin{array}{l}-.393 * \\
(.134) \\
-5.38\end{array}$ \\
\hline Income & $\begin{array}{c}.136^{*} \\
(.045) \\
6.42\end{array}$ & $\begin{array}{c}.096^{*} \\
(.041) \\
4.84\end{array}$ & $\begin{array}{l}.052 \\
(.035) \\
2.72\end{array}$ \\
\hline $\begin{array}{l}\text { University } \\
\text { Educated }\end{array}$ & $\begin{array}{l}-.132 \\
(.165) \\
-1.71\end{array}$ & $\begin{array}{l}-.112 \\
(.116) \\
-1.93\end{array}$ & $\begin{array}{l}.125 \\
(.115) \\
1.95\end{array}$ \\
\hline \multicolumn{4}{|c|}{ Party Identification } \\
\hline Attendance & $\begin{array}{l}.114^{*} \\
(.053) \\
4.46\end{array}$ & $\begin{array}{l}.094 * \\
(.045) \\
4.36\end{array}$ & $\begin{array}{l}.349 * * \\
(.075) \\
14.09\end{array}$ \\
\hline $\begin{array}{l}\text { Religious } \\
\text { Denomination }\end{array}$ & $\begin{array}{c}.340^{*} \\
(.127) \\
5.66\end{array}$ & $\begin{array}{l}.486 * * \\
(.116) \\
8.92\end{array}$ & $\begin{array}{l}.410 * * \\
(.152) \\
7.75\end{array}$ \\
\hline $\begin{array}{l}\text { Union } \\
\text { Member }\end{array}$ & $\begin{array}{l}-.341 * \\
(.151) \\
-4.95\end{array}$ & $\begin{array}{l}-.758^{* * *} \\
(.184) \\
-8.84\end{array}$ & $\begin{array}{l}-.731 * * \\
(.209) \\
-10.77\end{array}$ \\
\hline Income & $\begin{array}{c}.127^{*} \\
(.047) \\
6.30\end{array}$ & $\begin{array}{l}.147 * * \\
(.043) \\
7.48\end{array}$ & $\begin{array}{l}.098 \\
(.053) \\
5.51\end{array}$ \\
\hline $\begin{array}{l}\text { University } \\
\text { Educated }\end{array}$ & $\begin{array}{l}-.222 \\
(.174) \\
-2.98\end{array}$ & $\begin{array}{l}-.086 \\
(.120) \\
-1.52\end{array}$ & $\begin{array}{l}-.089 \\
(.170) \\
-1.54\end{array}$ \\
\hline
\end{tabular}

* Significant at the .05 level. ** Significant at the .001 level. The values presented are probit coefficients presented above their standard errors in parentheses, with probability changes for a one standard deviation change in the values of the respective independent variables. 
Figure S.1 Path Model of the Effects of Social Cleavages on Vote Choice

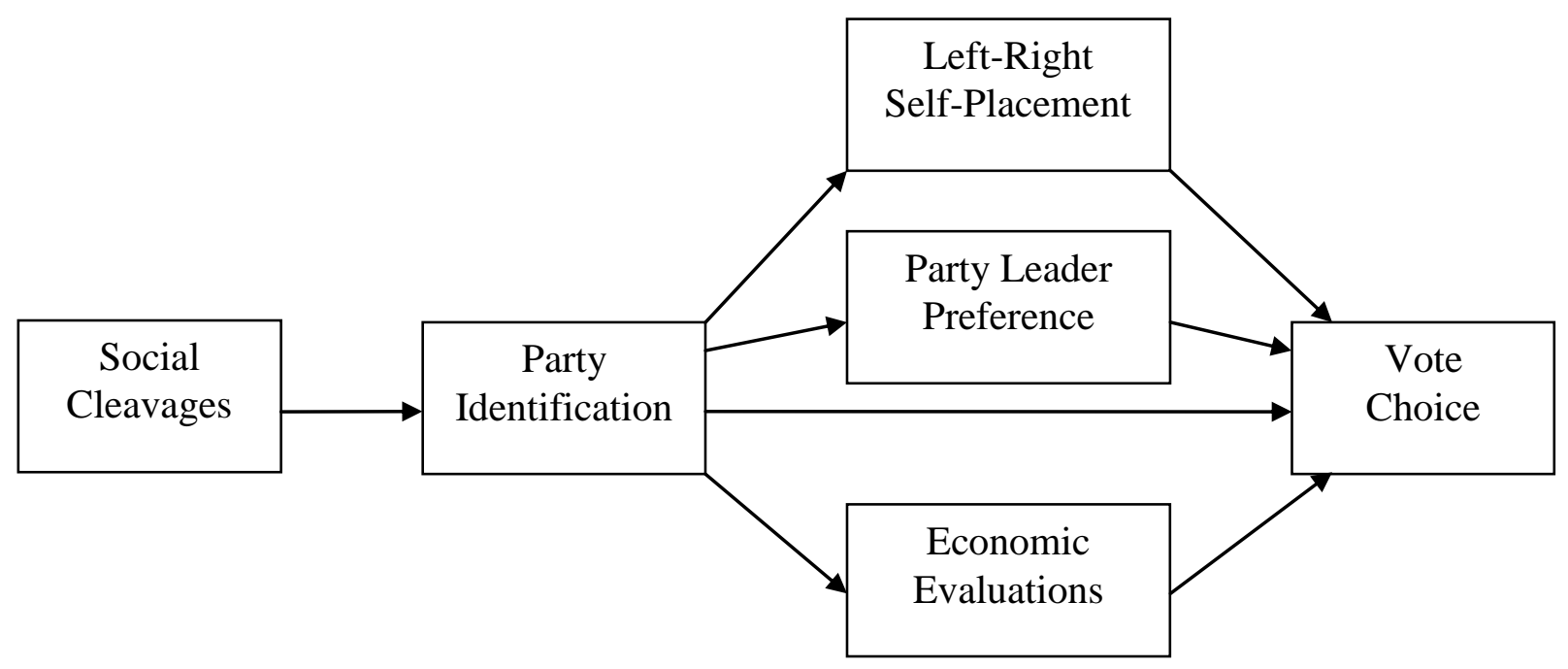




\begin{tabular}{|c|c|c|c|c|c|c|}
\hline \multicolumn{6}{|c|}{ Table S.2 Effects of Social Cleavages on More Proximal Vote Determinants } \\
(OLS Regression Coefficients, Controlling for Party Identification and Endogeneity)
\end{tabular}

* Significant at the .05 level. ** Significant at the .001 level. The values presented are unstandardized regression coefficients presented above their standard errors in parentheses. Only select coefficients are presented in the interest of space. 


\section{Table S.3 Changes in Probabilities}

\begin{tabular}{|c|c|c|c|}
\hline DV: Vote Choice & UK 1997 & US 1996 & GER 1998 \\
\hline Left-Right Self-Placement & 7.83 & 4.32 & 3.81 \\
\hline Party Leader Preference & 9.40 & 21.84 & 15.55 \\
\hline Economic Evaluations & -5.52 & 1.66 & -5.02 \\
\hline Party Identification & 66.81 & 73.02 & 40.94 \\
\hline Attendance & 25.51 & 31.50 & 30.05 \\
\hline Religious Denomination & 31.40 & 28.91 & 12.87 \\
\hline Union Member & -47.21 & -29.05 & -18.18 \\
\hline Income & 49.94 & 27.82 & 16.84 \\
\hline University Completed & -20.73 & 1.47 & 1.72 \\
\hline
\end{tabular}

Values represent the change in probability resulting from a one-standard deviation increase in the respective independent variable. Probabilities are for selected variables only. 


\begin{tabular}{|c|c|c|c|c|c|c|}
\hline \multicolumn{7}{|c|}{$\begin{array}{c}\text { Table S.4 Probit Model Parameter Estimates } \\
\text { (for the Probabilities Presented in Table } 4 \text { in the text) }\end{array}$} \\
\hline & \multicolumn{2}{|c|}{ UK 1997} & \multicolumn{2}{|c|}{ US 1996} & \multicolumn{2}{|c|}{ GER 1998} \\
\hline & 1 & 2 & 1 & 2 & 1 & 2 \\
\hline $\begin{array}{l}\text { Left-Right Self- } \\
\text { Placement }\end{array}$ & $\begin{array}{l}.270 * * \\
(.023)\end{array}$ & $\begin{array}{l}.270 * * \\
(.023)\end{array}$ & $\begin{array}{l}.233 * * \\
(.035)\end{array}$ & $\begin{array}{l}.233 * * \\
(.035)\end{array}$ & $\begin{array}{l}.182 * * \\
(.031)\end{array}$ & $\begin{array}{l}.182 * * \\
(.031)\end{array}$ \\
\hline $\begin{array}{l}\text { Party Leader } \\
\text { Preference }\end{array}$ & $\begin{array}{l}.229 * * \\
(.017)\end{array}$ & $\begin{array}{l}.229 * * \\
(.017)\end{array}$ & $\begin{array}{l}.546^{* *} \\
(.040)\end{array}$ & $\begin{array}{l}.546^{* *} \\
(.040)\end{array}$ & $\begin{array}{l}.225^{* *} * \\
(.025)\end{array}$ & $\begin{array}{l}.225^{* *} \\
(.025)\end{array}$ \\
\hline $\begin{array}{c}\text { Economic } \\
\text { Evaluations }\end{array}$ & $\begin{array}{c}-.486 * * \\
(.067)\end{array}$ & $\begin{array}{c}-.486^{* *} \\
(.067)\end{array}$ & $\begin{array}{l}.295^{* *} \\
(.075)\end{array}$ & $\begin{array}{l}.295^{* *} \\
(.075)\end{array}$ & $\begin{array}{l}-.094 * \\
(.045)\end{array}$ & $\begin{array}{l}-.094^{*} \\
(.045)\end{array}$ \\
\hline Attendance & $\begin{array}{l}.022 \\
(.037)\end{array}$ & $\begin{array}{l}.194 * * \\
(.038)\end{array}$ & $\begin{array}{l}.124 * \\
(.053)\end{array}$ & $\begin{array}{l}.333 * * \\
(.054)\end{array}$ & $\begin{array}{l}-.006 \\
(.061)\end{array}$ & $\begin{array}{l}.184 * \\
(.061)\end{array}$ \\
\hline $\begin{array}{c}\text { Religious } \\
\text { Denomination }\end{array}$ & $\begin{array}{l}.318 * * \\
(.093)\end{array}$ & $\begin{array}{l}.807 * * \\
(.096)\end{array}$ & $\begin{array}{c}.205 \\
(.122)\end{array}$ & $\begin{array}{l}.629 * * \\
(.123)\end{array}$ & $\begin{array}{l}.399 * * \\
(.122)\end{array}$ & $\begin{array}{l}.550 * * \\
(.123)\end{array}$ \\
\hline $\begin{array}{l}\text { Union } \\
\text { Member }\end{array}$ & $\begin{array}{l}-.283^{*} \\
(.105)\end{array}$ & $\begin{array}{c}-.691 * * \\
(.106)\end{array}$ & $\begin{array}{l}-.461^{*} \\
(.181)\end{array}$ & $\begin{array}{c}-.963 * * \\
(.184)\end{array}$ & $\begin{array}{c}-.577 * * \\
(.173)\end{array}$ & $\begin{array}{c}-.658 * * \\
(.172)\end{array}$ \\
\hline Income & $\begin{array}{l}.160 * * \\
(.033)\end{array}$ & $\begin{array}{l}.322 * * \\
(.034)\end{array}$ & $\begin{array}{l}.193 * * \\
(.057)\end{array}$ & $\begin{array}{l}.311 * * \\
(.059)\end{array}$ & $\begin{array}{l}.129 * \\
(.046)\end{array}$ & $\begin{array}{l}.184 * * \\
(.046)\end{array}$ \\
\hline $\begin{array}{l}\text { University } \\
\text { Completed }\end{array}$ & $\begin{array}{l}-.240 \\
(.130)\end{array}$ & $\begin{array}{l}-.318^{*} \\
(.130)\end{array}$ & $\begin{array}{c}.231 \\
(.131)\end{array}$ & $\begin{array}{l}.140 \\
(.129)\end{array}$ & $\begin{array}{l}-.191 \\
(.197)\end{array}$ & $\begin{array}{l}-.222 \\
(.197)\end{array}$ \\
\hline Women & $\begin{array}{c}.117 \\
(.089)\end{array}$ & $\begin{array}{l}-.049 \\
(.088)\end{array}$ & $\begin{array}{l}-.341^{*} \\
(.123)\end{array}$ & $\begin{array}{c}-.687 * * \\
(.126)\end{array}$ & $\begin{array}{c}.056 \\
(.123)\end{array}$ & $\begin{array}{l}-.039 \\
(.121)\end{array}$ \\
\hline Region & $\begin{array}{c}-.394 * * \\
(.122)\end{array}$ & $\begin{array}{c}-.570 * * \\
(.123)\end{array}$ & $\begin{array}{l}-.140 \\
(.130)\end{array}$ & $\begin{array}{l}-.088 \\
(.130)\end{array}$ & - & - \\
\hline Urban & - & - & $\begin{array}{l}-.083 \\
(.143)\end{array}$ & $\begin{array}{l}-.150 \\
(.143)\end{array}$ & $\begin{array}{l}-.159 \\
(.148)\end{array}$ & $\begin{array}{l}-.277 \\
(.149)\end{array}$ \\
\hline Black & - & - & $\begin{array}{c}-3.016^{* *} \\
(.534)\end{array}$ & $\begin{array}{c}-3.397 * * \\
(.539)\end{array}$ & - & - \\
\hline Constant & $\begin{array}{c}-2.666^{* *} \\
(.287)\end{array}$ & $\begin{array}{c}-2.129 * * \\
(.144)\end{array}$ & $\begin{array}{c}-6.376^{* *} \\
(.473)\end{array}$ & $\begin{array}{c}-2.140^{* *} \\
(.282)\end{array}$ & $\begin{array}{c}-2.823 * * \\
(.312)\end{array}$ & $\begin{array}{c}-1.565^{* *} \\
(.204)\end{array}$ \\
\hline $\begin{array}{l}\text { Likelihood } \\
\text { Ratio (df) }\end{array}$ & $\begin{array}{c}955.74 \\
(10)\end{array}$ & $\begin{array}{c}955.74 \\
(10)\end{array}$ & $\begin{array}{c}681.27 \\
(12)\end{array}$ & $\begin{array}{c}681.27 \\
(12)\end{array}$ & $\begin{array}{c}242.28 \\
(11)\end{array}$ & $\begin{array}{c}242.28 \\
(11)\end{array}$ \\
\hline $\begin{array}{l}\text { Pseudo R } \\
\text { (Cox-Snell) }\end{array}$ & .422 & .422 & .509 & .508 & .300 & .300 \\
\hline $\mathrm{n}$ & 1741 & 1741 & 958 & 958 & 680 & 680 \\
\hline
\end{tabular}

* Significant at the .05 level. ** Significant at the .001 level. The values presented are probit coefficients presented above their standard errors in parentheses. 